\title{
Research and Government:
}

\section{Feeding Knowledge into Public Policy}

\author{
Gary Hawke and Michael Wintringham
}

\section{Introduction}

Academic research on government may or may not be of value to those who govern today. It is, after all, motivated principally by the desire to advance knowledge, not to assist the public policy process at any given time. The latter may draw on, or be the specific motivation for, other research undertakings beyond academia. of course it is also the case that any research, regardless of its principal motivation or institutional setting, may advance both knowledge and the public policy process.

In pursuing its mission, the School of government at Victoria U niversity must seek to bridge the gap between academic research and enquiry which is linked directly to policy development. The latter can be generally referred to as "directed research" (and is in fact usually conducted in or for government agencies). Between this and academic research there may be few hard boundaries in real world discussions on knowledge and public policy. But there will always be underlying tensions - and debate over the value of particular research because of fundamentally different, yet equally legitimate, motivations.

In $\mathrm{N}$ ew Zealand, as elsewhere, it is not unknown for politicians and officials to bemoan the irrelevance of much of the academic research being funded by public expenditure. It is also common for researchers to bemoan the way the G overnment wants research of a very restricted kind and will not recognize the relevance, let alone the value, of really interesting research possibilities. Even when policy managers have a broad appreciation of research, and when researchers want to contribute to public issues as well as attract public funding, the coincidence of agendas tends to be limited by the difference in motivations.

\section{Academic research}

As a university institution, the School is concerned with "theadvancement of knowledgeand themaintenanceand dissemination thereof by teaching and research" (the traditional statutory formulation). Accordingly, it can bring academic expertise and knowledge to bear on the central issues of public sector capability, within the standard academic enterprise. The field of academic research and teaching must encompass the understandings of society held within the Government, wherethelatter is comprised of both politicians and officials. And it must include understanding the constraints which are imposed on the Government by other sectors of society, notably business entities, non-governmental organisations and bodies of public opinion.

W ithin our broad definitions of government and research, we start to see a long list of topics in which work has al ready been done, much of it within a range of disciplines that includes demography, economics, international relations, management, political scienceand sociology. It may have been classified under such problem-oriented or interdisciplinary areas as the "future of work", health policy, public sector management, public policy, or sustainable development. Research tends to proliferate in areas in which $\mathrm{N}$ ew Zealand policies and practices are of interest overseas. In the field of governance, the state sector reforms of recent decades have attracted significant international interest.

$O$ verseas researchers and practitioners look with interest on $\mathrm{N}$ ew Zealand's innovations in numerous other policy and management areas, including resource management, engagement with Treaty of Waitangi issues, genetic modification, and accident compensation and rehabilitation. In other policy and management fields, $\mathrm{N}$ ew Zealand researchers have taken advantage of the country's small size, diversity, and other specific characteristics to interest international audiences in 
universal themes, often as contributions to comparative research programmes.

In summary, academic research from diverse sources and disciplines can make contributions to the public policy process across the following range of themes:

- The N ew Zealand context, including the structures and institutions of government, historical conditions, legislation, and national identity;

- M ajor policy questions, which academic research has both informed and reacted to;

- Big public sector management and administration questions; and

- Achieving continuous improvements in practice in the operation of the government sector and the implementation of government policies.

There is significant value in these, even within the specific requirements of the Senior Leadership and $M$ anagement $D$ evelopment Project. H owever, there is a long-standing belief among $M$ inisters and officials that $\mathrm{N}$ ew Z ealand's research capacity is poorly aligned with national priorities. The idea of mis-alignment has been a particular element in tertiary education policy since the 1980s; the re-organisation of the science sector since the creation of Crown Research Institutes (and the subsequent response to the failure of the Social Science CRI); the "science envelope" and "futures" initiatives of the M inistry of Science and Technology; as well as the current activities of the Tertiary Education Commission. The underlying tensions, as referred to earlier, are as old as government interest in the (original) University of $\mathrm{N}$ ew Z ealand.

\section{Directed research}

The spectrum of research undertakings directly related to the policy process is also very broad. Indeed, merely elucidating the objectives of government is more problematic than is generally realized - outside the ranks of public servants for whom it is an important professional skill. Lobbyists can take the incidental remark of a minister (or even in some circumstances of a member of a Government political party) as an authoritative statement of G overnment objectives. Public policy researchers cannot be so cavalier. Governments occasionally make formal statements of objectives but it is in the nature of politics for these to be high order and framed with significant caution.

By way of illustration, we can use $N$ ew Zealand'scurrent statement of "Key Government Goals to Guide the Public Sector in Achieving Sustainable D evelopment." This reads as follows:

- Strengthen $\mathrm{N}$ ational Identity and U phold the Principles of the Treaty of Waitangi;

- Grow an Inclusive, Innovative Economy for the Benefit of All;

- M aintain Trust in Government and Provide Strong Social Services;

- Improve N ew Zealanders' Skills;

- Reduce Inequalities in Health, Education, Employment and H ousing; and

- Protect and Enhance the Environment.

These goals are not meaningless; they close off some policy positions which have political advocates. They were originally drawn up "to guide public sector policy and performance" and the subsequent inclusion of specific reference to "sustainable development" reflects a high-level policy decision. The fifth goal originally referred to "Close the Gaps for M aori and Pacific People..." instead of "Reduce Inequalities in etc..." and that amendment, too, reflected a high-level decision. $\mathrm{N}$ evertheless, such goals remain at a broad level of generality. This is equally true of the goals for research in the Tertiary Education Strategy. They identify concepts which researchers can discuss, and look for linkages which throw light on why an objective is desirable or explore the implications of pursuing an objective in a particular way.

The process of international economic integration which underlies the concept of an open competitive economy opens up many fields of enquiry. So does the concept of an "inclusive" society, which might sound innocuous, but is seen by some as diverting attention from issues of social stratification or class. Research which is motivated by a desire to enhance conceptual understanding will often lead into more specific enquiries.

Abstract reasoning in many fields is facilitated by realworld observation, and those empirical enquiries may relate to issues of interest to government departments or agencies delivering public services. There can, 
therefore, be direct linksbetween high-level government objectives and policy-related research. But thehigh-level objectives themselves create an agenda for researchers only in so far as they indicate some concepts where discussion is more likely to attract public interest.

\section{G overnment agendas}

The government may commit itself to somewhat more specific agendasin particular contexts. Thepolitical leaders of the current government have published papers with the authority of $\mathrm{C}$ abinet on their objectives in relation to sustainable development (as noted above) and with referenceto policiesaffecting families (by theestablishment of a Families Commission). TheC abinet has also published aformal "G rowth and Innovation Framework" and invited research on ways in which government can work with the private sector in promoting regional and industrial development. It hasstated theview that microbiology, ICT and cultural industriesare of special importance. It cannot be said with any confidence that such government statements of research priorities have great influence as signals to researchers.

The government has much greater influence on researchers through the processes and criteria it establishes for allocation of research funding. The government, acting on the advice especially of the $M$ inistry of Research Science and Technology, creates priorities for funds appropriated for research. There are various funds, most notably the $M$ arsden Fund, where the criteria emphasise qualities like innovation and originality. The Public G ood Science Fund criteria emphasise desired socio-economic outcomes. These various criteria are developed in consultation with researchers and with stakeholders in the end-use of research. At the end of the process, it can be difficult to see much connection with what the government has declared to be its high-order objectives.

Government also creates research agendas through questions posed as departments and agencies work on developing or implementing policy. N obody could doubt that therewould beintense interest from officials and $M$ inisters in any research which created simple rules about the optimal nature of the $C$ rown balance sheet. $\mathrm{N}$ or could anybody doubt that there would be equally intense interest in any research which gave greater understanding of the optimal public resourcing of child welfare agencies, or of how those resources should be managed. Answers to major questions which trouble governments are al ways welcome - and they are major questions because answers are not easy to find.

\section{Pressures on government}

Specific research may contribute to issues which are pressing across the public service. In early 2003, the School interviewed departmental chief executives about the major issues facing them. Each had his or her own list, related to their area of responsibility, but there were some common themes as well. These were matters of strategic policy management, or problem areas which reflected the overlap between policy issues and issues of public sector management. The three leading themes were:

- Problemsthat cut across conventional categorisation of policy areas and require responses from more than a single agency - the "whole of government" interest in "wicked issues" and therelated challenges of achieving "joined-up government";

- Problems that requireco-operation or collaboration between the public sector and some kind of community organisation - these may involve more abstract questions over the nature and legitimacy of governance, or at the other extreme, issues around achieving efficient service delivery;

- Recognition of a growing need to conceptualise policy issues and responses to them in an international rather than national framework concern that policy development in $\mathrm{N}$ ew Zealand could be judged inappropriate if it did not take account both of international obligations and the international implications of decisions taken here.

These themes derive from officials rather than politicians, but of course the priorities of the elected members of the Government tend to press heavily on the concerns of chief executives of departments. There are other strong pressures arising from $M$ inisters' needs to respond to issues which have come under public scrutiny. The public and media are inevitably interested in scandals and failures, and $M$ inisters expect the public service to be equipped to answer questions as soon as they are asked. 0 fficials must, therefore, be engaged in preparatory work before those questions are put, while also satisfying $M$ inisters that their other priorities are getting proper attention. 
G overnments want a public service which is innovative, able to respond to new challenges and not merely one which maintains familiar routines. Innovation and flexibility flow from learning by doing, and thisinvolves making changes when it is apparent that improvement is possible. Change itself - let alone the failed experiments that are inevitable in any process of change - can often beportrayed by thepublic, media or political opponents as an indicator of failure and scandal.

Perhaps the most fundamental challenge facing the public service is the creation and maintenance of trust on the part of both M inisters and the public - to the point whereboth separately believethat such innovation is to be welcomed. The broad agenda of public management and public policy must include the deliberate pursuit by public sector agencies of the kind of reputation that enables them to be creative and flexible in their approach. This line of thinking gives a high priority to research about the nature of ethical systems and of community trust. It promotes research of a conceptual kind - not unlike the work required to pursue the high-level objectives of government discussed above.

Consider the approach of social science researchers working outside the public service. They are morelikely to reflect on the same set of research questions and see common threads through categories familiar within the discipline. If this were to inform discussions within the public service, the focus would be on topics including risk, children, governance, integration/coordination/outcomes, public-private split, and the concept of a knowledge society. Whatever broad approach is taken, we will find a number of discussions where research themes interact with the debate on policy and public sector management.

\section{Research alignment}

A key challenge for both universities and public service organisations is to find constructive ways in which research priorities (and incentives) for academics and others can be aligned with the priorities of the government. It is, in fact, a challenge central to the future of our Parliamentary system, given the basic requirement for public servants who can faithfully serve the elected government of today while, at thesametime, building their capabilities to serve future governments. In other words, the ability to maintain focus on the medium- to long-term policy horizon is an essential professional skill.

There is no doubt that government participants and academics have difficulty working across institutional barriers. C areer structures in $\mathrm{N}$ ew Zeal and, and also in Australia, do not facilitate exchange and movement between the government, academia and research institutes (or other "think tanks"). We have to look elsewhere to develop high-powered academic researchers who can make important connections and translate knowledge from the world of ideas into practical applications for the world of public policy. If we want to grow knowledge and capability, we may need to examine the reward for academics and others who focus their research energies on real world policy and management issues. Intractable issues are rarely solved with the insights of a single discipline and we should recall the old adage, "if the only tool you have is a hammer, then all your problems seem like nails".

This is a period of increased transparency in government processes and greater complexity in political coalitions, across diverse ideologies and policy preferences. There is a danger that this will create an environment in which the potential of a more stable and capable public service is not fully realised. Some departments report, for instance, that they are now less able to shelter deep thinkers within their organisation than in former times.

O $n$ the other hand, some $\mathrm{N}$ ew Zeal and public agencies have been quick to embrace moves to establish egovernment web portals, and to pool data and information across agencies. $M$ any haveyet to establish robust research and knowledge management strategies in order to support the ongoing "business" of government. The development of scenarios, futures work and environmental monitoring is part of a growing set of tools that governments will have to employ to meet the challenge of fostering governance appropriate to the $21^{\text {st }}$ century.

There is surely a common interest in linking public sector analysis and advice more clearly to the evidence, and in emphasising more clearly its medium term and strategic dimensions. Can we specify the precise role of information, evidence and methods as inputs to policy development and decision-making in the public sector today? It would certainly be encouraging if we 
could demonstrate that policy advice is evidence-based in N ew Zealand. Much is said about embedding international best practice in public sector agencies. But such practice must be rigourously adjusted by those who are able to bring professional understanding of thelocal context. Perhaps thistellsus to foster creativity and innovation in those agencies in order to produce solutions based principally on applied research into, and close knowledge of, the $\mathrm{N}$ ew Zealand experience.

\section{The way forward}

The gulf between academia and the public service is much wider than need be. To some extent, the situation reflects limited awareness within each group about where comparative advantage might lie when it comes to examination of public policy and management priorities. The way forward is for clear definition of the critical policy and management issues. $C$ an this be arrived at by consensus among the end users of research? C an such a process in turn produce a greater commitment to link theory in an effective way with public sector practice?

The School seeks to lead in forging these linkages in support of its Tertiary Alliance with the Government and through its participation in the Australia N ew Zealand School of Government (or AN ZSoG for short). The latter offers several unique opportunities;

- Crossjurisdictional comparison. Therearemany broad similarities among the challenges facing the public services of $\mathrm{N}$ ew Zealand, the Commonwealth of Australia, and Australian states and territories. There are also differences. Exploration of these features could generate advances in our mutual understanding, together with highly practical lessons for policy development and service delivery in Australia and $\mathrm{N}$ ew Zealand.

- Case studies tracking significant developments in public policy and public sector management in either Australia or N ew Zealand.

- Practitioner reflectionson experienceand international thinking. Exchangesamong participantsin AN ZSoG courses create unusual opportunities to combine reflection on day-to-day practice with leading-edge thinking at the international level.

W ith these opportunities always in mind, the School is guided also by the priorities of the Tertiary Alliance.
This leads to a particular interest in improving knowledge about:

- Peopleand their values. There is a continual demand for better understanding of how management differs between theprivateand public sectors. Thisislinked in turn to the way in which changes in society impact on the ethics and values of public servants. There are challenges to conventions such as political neutrality (which vary across jurisdictions) as society becomes more litigious and conscious of the rights of both individuals and groups. Perhaps the most fundamental element here is the fact that the consent of the governed, on which democracy rests, will beincreasingly challenged by the decline of trust in public institutions. This has been observed internationally, and $\mathrm{N}$ ew Zealand isno exception to the trend.

- Organizational performance. D eveloping leaders and senior managers puts the focus on individuals, but theprocessalso requires more detailed understanding of how individuals work together in groups. A particular opportunity for cross-jurisdictional comparison arises from $\mathrm{N}$ ew Zealand's conception of departmental chief executives as employers, not just holders of a particular office in the policy process. There is always room for better understanding of how to achieve compatibility between "outcomes leadership" and efficient management of processes and budgets. We still have much to learn about the critical success factors of "managing for outcomes" and about identifying capabilities which are mission critical for specific organizations.

- The public management system. Key issues include managing innovation, so that certain safeguards are placed around any scope for experimentation. These must ensure that failure is used to bring about some element of learning and positive experience. Then there is the task of disseminating innovation from a pilot scale to effective application within a complete system. The core requirement in the next stage of people-focused management is to anticipate demographic changes. In parallel, managerswill have to make informed calculations about the impact of Information and communicationstechnology, or ICT.

- Working with NGOS. Because of the combination between strategic policy management and changes 
in the way governments will want to work, there will have to be a new capability to contract and cooperate with N GO s. M oreover, the enhanced focus on what citizens can bring to the policy process means that expectations on the part of public sector managers will continueto rise. Perhaps they will need a new blend of agility and consistency to succeed in their task.

In short, there is an array of valuable research possibilities in $\mathrm{N}$ ew Zealand. We need to take full advantage of the dialogue flowing within the Tertiary Alliance and through the Schools to guide decisions on research, both academic and government-directed. The tensions between research motivations may linger on, but they can be reduced. This can only help all those who are stakeholders in government administration including the public, who will ultimately judge the value of our effort.

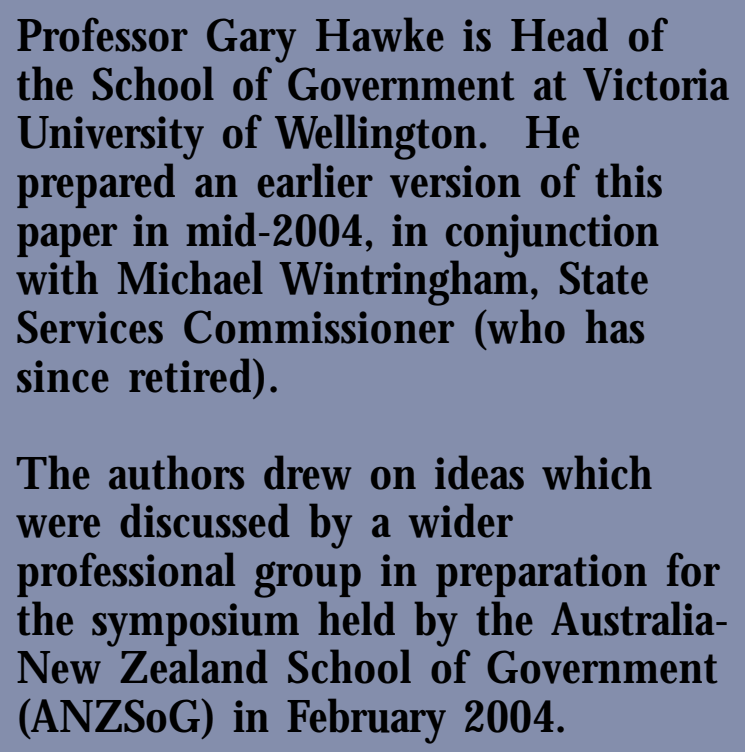

The authors drew on ideas which were discussed by a wider professional group in preparation for the symposium held by the Australia $\mathrm{New}$ Z ealand School of G overnment (ANZSoG) in February 2004. 